\title{
EFFECTIVENESS OF PROPRIOSEPTIVE NEUROMUSCULAR FACILITATION (PNF) AND KINESIOTAPING TOWARDS CHANGES IN MUSCLE STRENGTH AND ADL PATIENTS
}

\author{
Heni Kusumawati ${ }^{1 *}$, Maria Astrid ${ }^{2}$, Andreas Adyatmaka ${ }^{3}$ \\ ${ }^{1,2,3}$ STIK Sint Carolus \\ Email*: Sr.birgittasfs@gmail.com
}

\begin{abstract}
Introduction: Stroke in the form of neurological changes caused by disruption of blood supply to brain. The problem that is often experienced by sufferers is movement disorders. One of the non-pharmacological actions Proprioseptive Neuromuscular Facilitation (PNF) techniques are very practical to use and Kinesiotaping can also help improve sensomotor ability and muscle strength of patients after stroke. The purpose of this study was determine the effectiveness of PNF and Kinesiotaping for changes in muscle strength and ADL ability of stroke patients. Methods: Quasi Experiment Design pre and post test design with a control group. The number of samples was 204 respondents were divided into three intervention groups namely PNF (61 respondents), Kinesiotaping (61 respondents), and Joint Interventions (61 respondents) and control groups (21 respondents). Sampling techniques sample using Simple Random Sampling. Results: Parameters Test Estimates $P<0.05 P N F$ intervention results can be given a major influence on leg muscle strength $(P=0,000), M A S(P=0.004)$ and ADL $(P=0,000)$, Kinesiotaping gives a great influence on muscle strength hands $(P=0.024), \operatorname{MAS}(P=0.001), A D L(P=0.000)$ and Combined intervention have a an influence toward MAS $(P=0,000)$ and $A D L(P=0,000)$. Conclusions: The intervention that gives the most influence large is the Combine group against $A D L$ by 25,737 times compared to the group control. Suggestion: For hospitals to implement the three interventions and other factors such as psychology, motivation, physiological, mechanical, and neurological strength for stroke patients.
\end{abstract}

Keywords: adl; kinesiotaping; muscle strength; pnf; stroke

\section{INTRODUCTION}

Stroke is the term used for describe neurological changes that are caused by a disruption in blood supply to parts of the brain (Black, 2014). World Health Organization (WHO, 2010) defines stroke is a clinical manifestation of the disorder brain function, both focal and global (overall), which is fast, lasts more than 24 hours or until cause death, without other causes besides vascular disorders. Stroke is the third leading cause of death in the world after coronary heart disease and cancer both in developed countries and developing. One in 10 deaths are caused by stroke (Basid, Negara, 2017).

Indonesian Demographic and Health Survey (SKDI, 2010). Globally, 15 million people strokes every year, one third died and the rest have disabilities permanent (forum stroke, 2015). In area Southeast Asia there are 4.4 million people having a stroke. In 2020 an estimated 7.6 people died because of this stroke (Misbach, 2010). Indonesia ranks first in Asia, whereas according to Basic Health
Research (Riskesdas, 2011) likely to die due to stroke around $30-35 \%$ and experience $35-40 \%$ disability (Irfan, 2014). Mardi Lestari General Hospital, Stroke is a disease number 3 after Hypertension, Diabetes Mellitus.

The latest data in 2016 there were 1020 patients (Mardi Lestari Public Hospital Medicinal Data, 2016) good outpatients and inpatients. Data stroke patients at Mardi Lestari Public Hospital experiencing post-stroke pain \pm $60 \%$, contracture $30 \%$, and $40 \%$ spastic so affect the ADL function (Activities of Daily Living). ROM is given as a patient therapy post stroke, given in a week 2 times. Problems that are often experienced by sufferers stroke is a movement disorder, clinically symptoms that often appear are hemiparesis. Stroke rehabilitation in the form of movement exercises is a prerequisite for achieving it patient independence because exercise will helps to gradually function limbs and arms back or approaching normal, and gives strength to the patient to control his life (Irdawati, 2012).

PNF $\begin{gathered}\text { Treatment with } \\ \text { (Proprioceptive }\end{gathered}$ Neuromuscular


Facilitation) very practical use in efforts therapeutic, this technique is essentially provide stimulation to proprioceptors to increase the needs of neuromuscular mechanism, so obtained easy response. Besides PNF, Kinesiotaping can also help improve sensorimotor abilities of patients after stroke. Kinesiotaping can increase proprioception feedback so as to produce body position That's right, this is the basis for training to restore the function of the extremity. Kinesiotaping through receptors in cutaneous can

provide stimulation to the system neuromuscular in activating nerve performance muscles when doing a functional motion, besides kinesiotaping can also facilitate mechanoreceptors to direct the movement which is suitable and gives comfort to paired area (Irfan, 2014).

\section{METHODS}

This research uses quantitative methods with a pre Quasi Experiment research design and post test design with a control group. The number of samples in the study was 204 respondents were divided into three groups intervention namely PNF as many as 61 respondents, Kinesiotaping as many as 61 respondents, and Combined Interventions 61 respondents as well control group of 21 respondents. Evaluation this research was conducted on day 9 to PNF and 7th day for Kinesiotaping after intervention. The sampling technique Simple Random Sampling is used. Pretest and Posttest results are processed with use SPSS to find out the most influential intervention on changes in muscle strength and ADL ability (Susilo, 2014). Univariate analysis was used to find out the distribution of characteristics respondents on muscle strength and ADL in frequency and percentage. After data characteristics of muscle strength and ADL in each group, done paired difference test analysis and different test independent.

Paired different tests were performed by using a non parametric difference test with the Wilcoxon test to find out differences in muscle strength and ADL before and after the intervention (before-after) on the third intervention group. Non independent difference test parametric using test
Mann-Whitney to find out the difference average muscular strength and ADL between group, then do the analysis multivariate with ordinal logistic regression test to find out the effect of each variable is independent of dependent variable so that it is known variable independent who has the most influence strong against changes in muscle strength and ADL ability in stroke patients.

Based on the research ethical feasibility statement this research is ethical. This study has been conducted in hold principle of research ethics like anonymity, autonomy, veracity, beneficence, justice and informed consent also.

This study was approved by the Ethical Commission Of health Research, Institute Health Science Cahaya Bangsa Registration KEPK RI: 6303012S Number: 312/etik-stikes/I/2020.

\section{RESULTS}

Table 1. Difference before and after intervention with a non paired difference test parametric

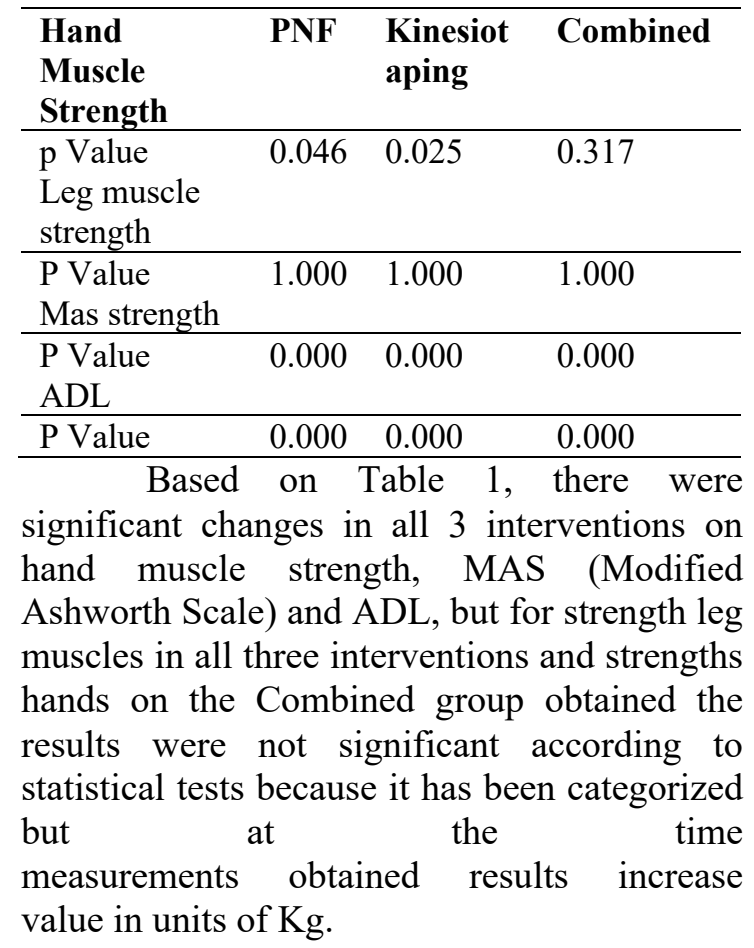

Table 2. Mann-Whitney Independent Difference Test Intervention groups with control group 


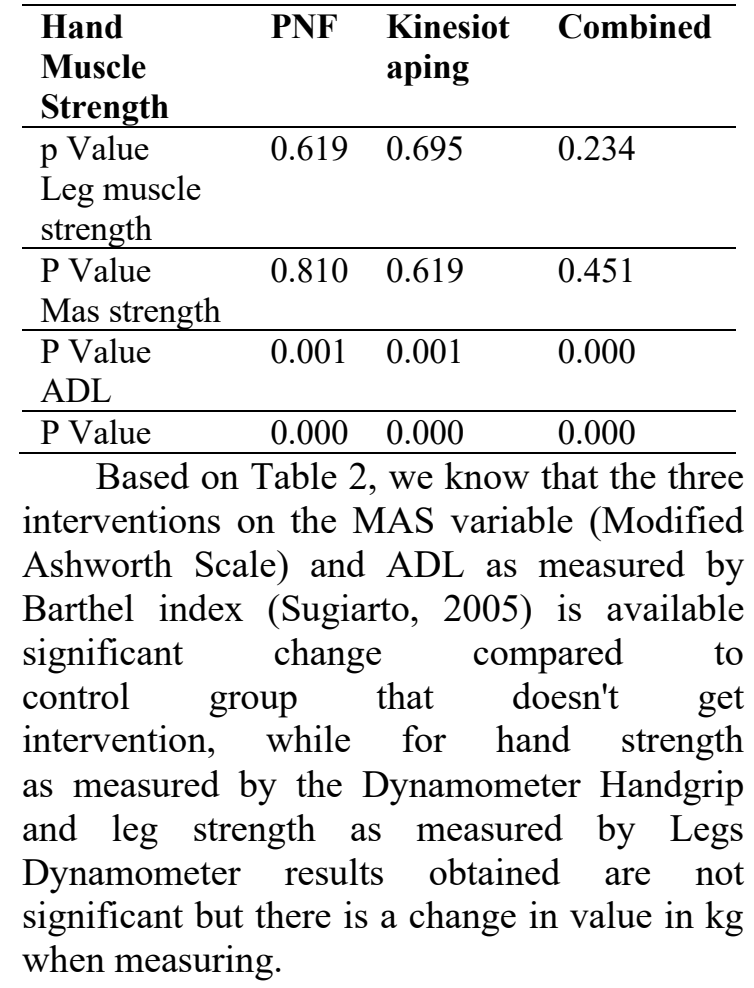

\section{a. Test Parameters Estimates}

Table 3. Test Parameters Estimates variables independent of muscle strength and $A D L$

\begin{tabular}{llll}
\hline $\begin{array}{l}\text { Hand } \\
\text { Muscle } \\
\text { Strength }\end{array}$ & PNF & $\begin{array}{l}\text { Kinesiot } \\
\text { aping }\end{array}$ & Combined \\
\hline $\begin{array}{l}\text { p Value } \\
\text { Leg muscle } \\
\text { strength }\end{array}$ & & 0.024 & \\
\hline $\begin{array}{l}\text { P Value } \\
\text { Mas strength }\end{array}$ & 0.000 & & \\
\hline $\begin{array}{l}\text { P Value } \\
\text { ADL }\end{array}$ & 0.004 & 0.001 & 0.000 \\
\hline P Value & 0.000 & 0.000 & 0.000 \\
\hline
\end{tabular}

\section{b. Parallel Lines Test}

Table 4. Parallel Lines Test intervention group and confounding simultaneously influence on hand muscle strength, leg muscle strength, MAS and ADL

\begin{tabular}{llll}
\hline $\begin{array}{l}\text { Hand } \\
\text { Muscle } \\
\text { Strength }\end{array}$ & PNF & $\begin{array}{l}\text { Kinesiot } \\
\text { aping }\end{array}$ & Combined \\
\hline $\begin{array}{l}\text { p Value } \\
\text { Leg muscle } \\
\text { strength }\end{array}$ & 0.995 & & 0.909 \\
\hline $\begin{array}{l}\text { P Value } \\
\text { Mas strength }\end{array}$ & & & 0.451 \\
\hline $\begin{array}{l}\text { P Value } \\
\text { ADL }\end{array}$ & 0.478 & 0.626 & 0.409 \\
\hline
\end{tabular}

\begin{tabular}{lll}
\hline P Value & 0.541 & 0.898 \\
\hline
\end{tabular}

\section{c. Cox and Snell Test}

In the Combined intervention with the strength variable feet produced cox and snell value of 0.750 statistically means variable independent (Combined intervention, age, type venereal and comorbidities) give the biggest contribution to variable leg muscle strength of $75.0 \%$ and the remaining $25.0 \%$ is explained by variables outside the model or variable not examined like psychological, motivation, strength physiology, mechanics and neurology.

\section{d. Probability Of An Event and Ratio Test}

Of the three PNF interventions, Kinesiotaping and Combined each gives influence on muscle strength and ADL. In the combined intervention the results are obtained the highest interventions are give effect to ADL by 25,737 times compared to control group.

\section{DISCUSSIONS}

At the time of the study, researchers found more many elderly respondents both Outpatient and inpatient who suffered a stroke than young age, in an average day control stroke patient visits in the room Nerve Poly $\pm 20-30$ patients and Inpatients with patient visits $\pm 5-10$ patients. Incident stroke increases after the age of 55 years, the wall blood vessels consisting of intima tunica, tunica media and tunica adventitia in the network the brain seems very thin even though elastic, but the accumulation of the development of plaque atherosclerosis in blood vessels

plays an important role in occlusion of arteries by thrombus or embolism that will result disruption of cerebral or cerebral blood flow Blood Flow (CBF) so activity oxygen and glucose metabolism in the brain will cease which results in death neuron cells (Negara,2017).

Experience more stroke compared to men. Researcher found a very significant increase where women have a stroke in the elderly has several diseases accompanying hypertension, DM, AF, Dyslipidemia (Negara, 2017) 
Researchers found many stroke patients with hypertension, according to Record data Medically that hypertension is a sequence disease First, this is due to heredity, economic problems in the family and post power syndrome for retirees who don't can accept the life that is experienced. This matter also in accordance with research (Abdul, 2009 ) that out of 42 stroke sufferers became a respondent as many as 33 people suffered hypertension.

According to (Alligood, 2014) the occurrence an increase in blood pressure can cause Further neurological damage with exacerbating cerebral edema. Hypertension indeed a major risk factor of stroke, because it can cause rupture of blood vessels, otherwise it can triggers the process of atherosclerosis by high pressure can drive LDL to more easily enter the intima layer lumen of the blood vessels and decrease elasticity of blood vessels. Bleeding most intracerebral caused by presence of arteriosclerotic rupture and hypertension blood vessels, which causes bleeding into brain tissue. Bleeding intracerebral most often results from hypertension and generally occurs after the age of 50 years, (Black, 2014).

Significant changes occurred in the 3rd intervention of hand muscle strength, MAS (Modified Ashworth Scale) and ADL, but for leg muscle strength in all three interventions and hand strength in the Combined group results were not significant according to the test statistics because it's been categorized but at the time of measurement the results are obtained increase in value in units of $\mathrm{kg}$. On research on giving PNF to strength of function in stroke patients hemorrhagic and non-hemorrhagic effects proven from the results of research with using statistical analysis the value of $\mathrm{P}=0.011$ (Woo-Il Kim, 2014).

From the results of the study shown how the function of kinesiotaping help with muscle strength and obtain methods kinesiotaping was more significant with $\mathrm{p}$ $<0.05$ (Irfan, 2014). Kinesiotaping can help improve the sensorimotor abilities of patients post stroke. Kinesiotaping can improve proprioceptive feedback to produce correct body position, this is the basis when training to restore function from extremities. Kinesiotaping through the receptor at cutaneous can provide stimulation to neuromuscular system in activating muscle nerve performance when doing a motion functional, besides kinesiotaping can also facilitate preceptors for direct the appropriate movement and gives a sense of comfort in the area paired (Irfan, 2014).

The results of PNF interventions have an impact great effect on leg muscle strength, MAS and ADL, for Kinesiotaping interventions give a big influence on hand muscle strength, MAS and ADL, for Combined intervention exerts influence which is big against MAS and ADL in rice stroke. In the study of Ali, et al, 2016 was obtained significant results of Kinesiotaping against pain reduction so strength muscles stay awake. Kinesiotaping Installation in the muscles is useful for reducing streaking pain so that it can increase degrees scope of joint motion, normalize length and tension from the muscles for maximum power, help heal muscle tissue, reduce muscle fatigue, facilities (increase contraction in muscles that are experiencing weakness) and inhibition (stimulation relaxation of the muscles to contract excessive).

\section{CONCLUSIONS}

Research on the effectiveness of interventions Proprioceptive Neuromuscular Facilitation (PNF), and Kinesiotaping, towards change muscle strength and ability of Activities of Daily Living (ADL) in stroke patients gives its influence great for leg muscle strength, MAS (Modified Ashworth Scale) and ADL, Kinesiotaping gives a big influence on the strength of the hand muscles, MAS, ADL and combined intervention exerts influence which is big towards MAS (Modified Ashworth Scale) and ADL through the parameters estimates test and the results obtained from odds ratio test from third intervention that gives influence the largest is the combined group against ADL by 25,737 times compared with a control group.

\section{REFERENCES}


Abdul G. (2009). Manjemen Stroke. Yogyakarta : Pustaka Cendikia Press.

Alligood. (2014). Nursing Theorists and Their Work . Eighth Edition.

American Heart Association. (2014). HeartDisease and Stroke Statistics .

Black, J. M. (2014). Keperawatan Medikal Bedah. Indonesia: Salemba Medika.

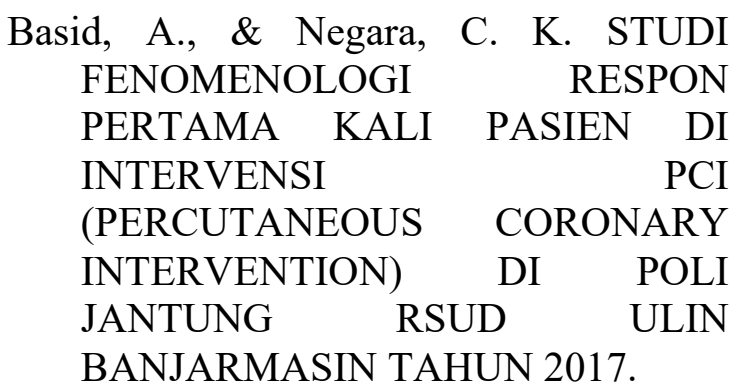

Irdawati. (2012). Pengaruh Latihan Gerak Terhadap Keseimbangan Pasien Stroke Non Hemoragik . Jurnal Kesehatan Masyarakat. Kemas 7 (2), 129-136.

Irfan, M. (2014). Fisioterapi Bagi Insan Stroke. Yogyakarta : Graha Ilmu.

Irfan M. (2014). Metode Konvensional Kinesiotaping, Dan Motor Relearning Programme Berbeda Efektivitas Dalam Meningkatkan Pola Jalan Post Stroke Di Klinik Ontoseno Malang . Sport and Fitness Journal. Pasien Volume 2, No. 1 : 72-133.

Misbach, Jusuf. (2010). Management of Cholesterol to Reduce Burden of Stroke in Asia : Consensus Statement. Jounal of Stroke; 5(3), hal : 209-216.

Negara, C. K. (2017). POST AMPUTATION RESPONSE AND COPING OF DIABETES MELLITUS PATIENT IN ULIN GENERAL
HOSPITAL BANJARMASIN. Jurnal Ilmu Keperawatan, 5(2), 114-129.

Negara, C. K., Basid, A., Erliani, S., \& Turahman, I. (2019). The Relationship Between Discharge Planning and The Quality of Life of Patients with Diabetic Ulcer. INDONESIAN NURSING JOURNAL OF EDUCATION AND CLINIC (INJEC), 4(1), 20-24.

Reni.Prima Gusty. (2012). Efektivitas Pemberian Mobilisasi Dini Terhadap Tonus Otot, Kekuatan Otot, dan Kemampuan Motorik Fungsional Pasien Hemiparise Paska Stroke Iskemik . Ners Jurnal Keperawatan. Volume 8, No 1, 40-47.

Riset Kesehatan Dasar (Riskesdas). (2011). Badan Pengembangan dan Penelitian Kesehatan Kementrian Kesehatan Republik Indonesia . Stroke Forum. (2015). Epidemiology of Stroke .

Survei Demografi dan Kesehatan Indonesia (SDKI). (2010). Profil Kesehatan Indonesia .

Susilo, W. (2014). Biostatistika Lanjut dan Aplikasi Riset . Jakarta : TIM. Wahyuddin. (2014). Pengaruh Pemberian PNF Terhadap Kekuatan Fungsi Prehension Pada Pasien Stroke Hemoragik Dan Non Hemoragik. Jurnal Fisioterapi Indonusa . Vol. 8 N0 1.

Woo-Il Kim, MSc, et al. 2014. The effect of muscle facilitation using kinesiotaping on walking and balance of stroke patients . J. Phys. Ther. SCi. 26 : 18311834.

World Health Organization. (2010). The Atlas of Heart Disease and Stroke. 